\title{
Sulfuricurvum kujiense gen. nov., sp. nov., a facultatively anaerobic, chemolithoautotrophic, sulfur-oxidizing bacterium isolated from an underground crude-oil storage cavity
}

\author{
Yumiko Kodama and Kazuya Watanabe \\ Laboratory of Applied Microbiology, Marine Biotechnology Institute, 3-75-1 Heita, Kamaishi, \\ Iwate 026-0001, Japan
}

Correspondence

Yumiko Kodama

yumiko.kodama@mbio.jp

\begin{abstract}
A facultatively anaerobic, chemolithoautotrophic, sulfur-oxidizing bacterium, strain $\mathrm{YK}-1^{\top}$, was isolated from an underground crude-oil storage cavity at Kuji in Iwate, Japan. The cells were motile, curved rods and had a single polar flagellum. Optimum growth occurred in a low-strength salt medium at $\mathrm{pH} 7 \cdot 0$ and $25^{\circ} \mathrm{C}$. It utilized sulfide, elemental sulfur, thiosulfate and hydrogen as the electron donors and nitrate as the electron acceptor under anaerobic conditions, but it did not use nitrite. Oxygen also served as the electron acceptor under the microaerobic condition $\left(\mathrm{O}_{2}\right.$ in the head space $1 \%$ ). It did not grow on sugars, organic acids or hydrocarbons as carbon and energy sources. The DNA G $+\mathrm{C}$ content of strain $\mathrm{YK}-1^{\top}$ was $45 \mathrm{~mol} \%$. Phylogenetic analysis, based on the 16S rRNA gene sequence, showed that its closest relative was Thiomicrospira denitrificans in the 'Epsilonproteobacteria', albeit with low homology (90\%). On the basis of physiological and phylogenetic data, strain $\mathrm{YK}-1^{\top}$ should be classified into a novel genus and species, for which the name Sulfuricurvum kujiense gen. nov., sp. nov. is proposed. The type strain is $\mathrm{YK}-1^{\top}\left(=\mathrm{JCM} 11577^{\top}=\mathrm{MBIC} 06352^{\top}=\right.$ ATCC BAA-921 $\left.{ }^{\top}\right)$.
\end{abstract}

In one of our previous studies, molecular ecological approaches showed that a group of bacteria (designated cluster-1 bacteria) affiliated with the Thiovulum subgroup (Maidak et al., 1999) in the 'Epsilonproteobacteria' constituted the major bacterial population in groundwater accumulated at the bottom of an underground crude-oil storage cavity at Kuji in Iwate Prefecture, Japan (Watanabe et al., 2000). The Thiovulum subgroup is a phylogenetic group that includes several sulfur-oxidizing bacteria, such as Thiomicrospira denitrificans (isolated from marine mud; Timmer-ten Hoor, 1975) and Thiomicrospira sp. strain CVO (isolated from the production water of an oil well; Gevertz et al., 2000), and many environmental clones of 16S rRNA genes (obtained from hydrothermal vents; Corre et al., 2001; Moyer et al., 1995), marine sediments (Madrid et al., 2001) and cave springs (Engel et al., 2003). Later, a bacterial strain (strain $\mathrm{YK}-1^{\mathrm{T}}$ ) that represented the cluster-1 bacteria was isolated and physiologically characterized (Kodama \& Watanabe, 2003). Strain $\mathrm{YK}-1^{\mathrm{T}}$ is the first and sole bacterium in the

Published online ahead of print on 19 July 2004 as DOI 10.1099/ ijs.0.63243-0.

The GenBank/EMBL/DDBJ accession number for the 16S rRNA gene sequence of strain $\mathrm{YK}-1^{\top}$ is $\mathrm{AB053951.}$

A sequence similarity matrix for strain $\mathrm{YK}-1^{\top}$ and related genera is available as supplementary material in IJSEM Online.
Thiovulum subgroup and was isolated from a freshwater environment. It is a sulfur-oxidizing chemolithotroph capable of growth by oxidizing sulfur compounds in crude oil as the energy sources (Kodama \& Watanabe, 2003). Based on its physiological and phylogenetic characteristics, we describe strain $\mathrm{YK}-1^{\mathrm{T}}$ as Sulfuricurvum kujiense gen. nov., sp. nov.

Strain YK-1 ${ }^{\mathrm{T}}$ was isolated by directly streaking the groundwater on agar plates containing DSM medium 113 (used for cultivating nitrate-reducing thiosulfate-oxidizing bacteria) (DSMZ catalogue). Colonies formed on the plates were analysed by sequencing their $16 \mathrm{~S}$ rRNA genes, and a strain, named $\mathrm{YK}-1^{\mathrm{T}}$, was found to have a $16 \mathrm{~S}$ rRNA gene sequence identical to that of a cluster-1 bacterium (Kodama \& Watanabe, 2003). The growth of strain $\mathrm{YK}-1^{\mathrm{T}}$ in DSM medium 113 was, however, not efficient, and we have developed a low-ion-strength medium (MBM) suitable for freshwater sulfur-oxidizing chemolithotrophs. MBM comprised $\left(l^{-1}\right) \quad 0.2 \mathrm{~g} \quad \mathrm{KH}_{2} \mathrm{PO}_{4}, 0.2 \mathrm{~g} \quad \mathrm{NH}_{4} \mathrm{Cl}, 0.4 \mathrm{~g}$ $\mathrm{MgCl}_{2} \cdot 6 \mathrm{H}_{2} \mathrm{O}, 0 \cdot 2 \mathrm{~g} \mathrm{KCl}, 0 \cdot 1 \mathrm{~g} \mathrm{CaCl}_{2} \cdot 2 \mathrm{H}_{2} \mathrm{O}, 0 \cdot 2 \mathrm{~g} \mathrm{NaNO}$, $2 \mathrm{mg}$ resazurin and $2 \mathrm{ml}$ trace element solution SL-4 (DSMZ catalogue). Solid media contained 1.5\% Bactoagar (Difco). For anaerobic cultivation, freshly prepared $\mathrm{Na}_{2} \mathrm{~S} .9 \mathrm{H}_{2} \mathrm{O}(2 \mathrm{mM})$ was used as a reducing agent unless otherwise specified, and it could also serve as the energy source. Routine cultivation was conducted without shaking 
at $25^{\circ} \mathrm{C}$ in a bottle capped with a Teflon-coated butylrubber septum and sealed with an aluminium crimp seal. The vapour phase in the bottle was filled with $\mathrm{N}_{2} / \mathrm{CO}_{2}$ $(80: 20 \%, \mathrm{v} / \mathrm{v}), \mathrm{N}_{2} / \mathrm{CO}_{2} / \mathrm{H}_{2}(80: 10: 10$, by vol.) or pure $\mathrm{N}_{2}$. For monitoring growth, cells in liquid culture were counted by epifluorescence microscopy after staining with 4',6-diamidino-2-phenylindole (DAPI) as described previously (Kodama \& Watanabe, 2003). Cells of YK-1 ${ }^{\mathrm{T}}$ were stored at $-80{ }^{\circ} \mathrm{C}$ in liquid MBM supplemented with $15 \%$ $(\mathrm{v} / \mathrm{v})$ glycerol.

Cell morphology was examined by transmission and scanning electron microscopy (Beveridge et al., 1994). Motility was checked by phase-contrast microscopy. Gram staining, oxidase and catalase tests were conducted according to standard procedures (Smibert \& Krieg, 1994). Effects of temperature, $\mathrm{pH}$ and salinity $(\mathrm{NaCl}$ concentration) on growth were examined in MBM. Buffer systems used for changing $\mathrm{pH}$ of the medium have been described elsewhere (Gevertz et al., 2000). G+C content was determined by HPLC according to the method of Mesbah et al. (1989).

Aerobic growth was examined in MBM without nitrate (the head space was sterilized air) supplemented with each of the following electron donors ( $2 \mathrm{mM}$ except for elemental sulfur): sulfide, thiosulfate, acetate, pyruvate, succinate, fumarate, lactate, glucose, formate, malate, glutamate, benzoate, phenol, octane, toluene, benzene and elemental sulfur $(1 \%, \mathrm{w} / \mathrm{v})$. Microaerobic growth [oxygen in the head space was $1 \%(\mathrm{v} / \mathrm{v})]$ was tested in MBM without nitrate (the head space was filled with $\mathrm{N}_{2} / \mathrm{CO}_{2}=80: 20$ ). Electron donors tested included sulfide ( $2 \mathrm{mM})$, thiosulfate $(2 \mathrm{mM})$, $\mathrm{H}_{2}$ (10\% in the head space) and elemental sulfur (1\%). Titanium(III) citrate $(1 \cdot 3 \mathrm{mM})$ was used as a reducing agent (Lomans et al., 1999), when the medium did not contain sulfide. Anaerobic growth (the head space was $\left.\mathrm{N}_{2}: \mathrm{CO}_{2}=80: 20\right)$ was examined in modified MBM, containing sulfide $(2 \mathrm{mM})$, thiosulfate $(2 \mathrm{mM}), \mathrm{H}_{2}$ (the head space was $\left.\mathrm{N}_{2}: \mathrm{CO}_{2}: \mathrm{H}_{2}=80: 10: 10\right)$ or elemental sulfur $(1 \%)$ as the electron donor and nitrate $(0.6 \mathrm{mM})$ or nitrite $(0 \cdot 7 \mathrm{mM})$ as the electron acceptor. Titanium(III) citrate $(1.3 \mathrm{mM})$ was used as a reducing agent. Fermentative growth was examined in MBM without nitrate and sulfide (the head space was $\mathrm{N}_{2}: \mathrm{CO}_{2}=80: 20$ ) supplemented with one of the following substrates $(2 \mathrm{mM})$; acetate, pyruvate, succinate, fumarate, malate, aspartate, lactate or glucose. Ascorbate $(2 \mathrm{mM})$ was added as a reducing agent for this test; strain $\mathrm{YK}-1^{\mathrm{T}}$ was unable to utilize ascorbate. In growth test with organic compounds $(2 \mathrm{mM}$ methanol, formate, acetate, pyruvate, succinate, fumarate, lactate, glucose, malate, glutamate, phenol, benzoate or octane) as electron donor, MBM (head space was $\mathrm{N}_{2}: \mathrm{CO}_{2}=80: 20$ ) was used in which nitrate served as an electron acceptor. Carbon-source utilization was examined in MBM containing sulfide as the electron donor and nitrate as the electron acceptor under anaerobic conditions (the head space of the bottle was filled with deoxygenated $\mathrm{N}_{2}$ ). Test compounds
(2 mM) included bicarbonate, acetate, glucose, octane, toluene and benzene.

Phylogenetic analysis based on the 16S rRNA gene sequence was conducted as described previously (Watanabe et al., 2000). The profile alignment technique of CLUSTAL $\mathrm{W}$ version 1.7 (Thompson et al., 1994) was used to align the sequences, and the alignments were refined by visual inspection; secondary structures were considered for the refinement (Gutell, 1994). The pairwise evolutionary distances based on 1232 unambiguous bases of the YK-1 ${ }^{\mathrm{T}}$ sequence were determined by the method of Jukes \& Cantor (1969) using PHYLIP version 3.572. For reference strains described below, the distances were estimated based on sequences of shorter fragments; Thiovulum sp. (639 bp), Hydrogenimonas thermophila (862 bases), strain CVO (1102 bases) and FWKO B (1102 bases). A phylogenetic dendrogram was constructed by using the njplot program in CLUSTAL $\mathrm{W}$ version 1.7.

The optimum growth conditions of strain YK- $1^{\mathrm{T}}$ were $25^{\circ} \mathrm{C}$ and $\mathrm{pH} 7 \cdot 0$. Addition of $\mathrm{NaCl}$ suppressed growth, and the best growth was observed in $\mathrm{MBM}$ in the absence of $\mathrm{NaCl}$. This feature was quite different from the salt requirement of Thiomicrospira denitrificans and Thiomicrospira sp. CVO. This difference is, however, understandable because YK- $1^{\mathrm{T}}$ was isolated from the freshwater environment, while Thiomicrospira denitrificans was isolated from marine sediment and strain $\mathrm{CVO}$ from a petroleum reservoir undergoing produced-water re-injection.

Cells of strain $\mathrm{YK}-1^{\mathrm{T}}$ were Gram-negative, curved rods (spiral cells were also observed in the exponential phase of growth), $0 \cdot 4 \mu \mathrm{m}$ wide and 1-2 $\mu \mathrm{m}$ long (Fig. 1). They are motile and have one polar flagellum (Fig. 1). The oxidase reaction was positive, while the catalase reaction was negative. Strain $\mathrm{YK}-1^{\mathrm{T}}$ was an obligate chemolithotroph, utilizing nitrate and oxygen as electron acceptors, and sulfide, thiosulfate, elemental sulfur and hydrogen as electron donors under microaerobic and anaerobic conditions. It could not grow on nitrite, and nitrite was the final product of nitrate reduction. Sugars, organic acids (including

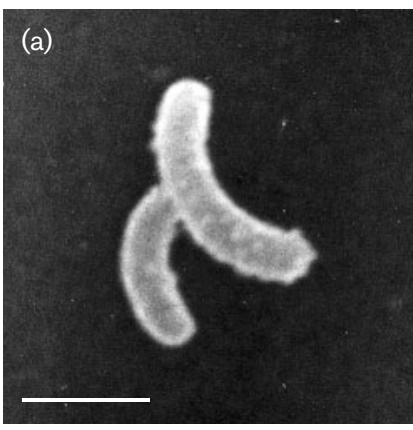

(b)

Fig. 1. Scanning (a) and transmission (b) electron micrographs of strain $\mathrm{YK}-1^{\top}$. Bar is $1 \cdot 2 \mu \mathrm{m}$, which also applies to part (b). 


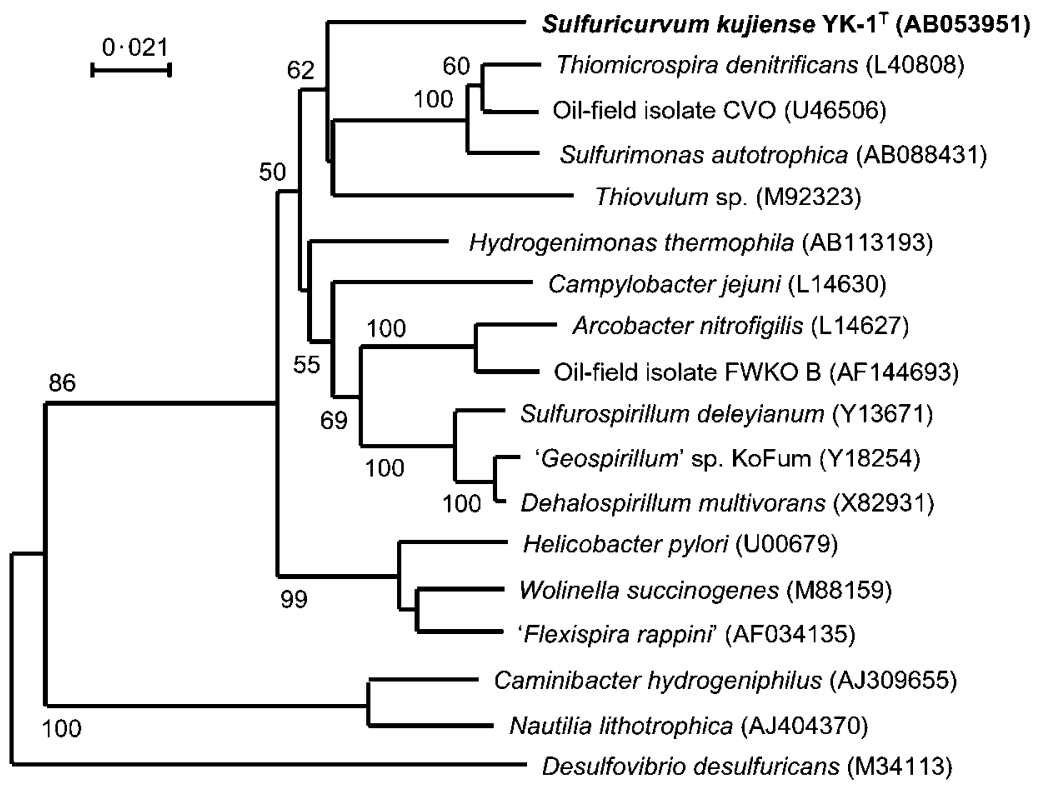

Fig. 2. Phylogenetic dendrogram based on 16S rRNA gene sequence comparison, showing the position of strain $\mathrm{YK}-1^{\top}$ and related genera within the 'Epsilonproteobacteria'. Accession numbers for the sequences retrieved from the databases are given in parentheses. Numbers at the branch nodes are bootstrap values (per 100 trials); only values greater than or equal to 50 are shown. Bar, 0.021 substitution per site.

acetate) and hydrocarbons could not serve as carbon and energy sources. The DNA G $+\mathrm{C}$ content of strain $\mathrm{YK}-1^{\mathrm{T}}$ was $45 \mathrm{~mol} \%$ as determined by HPLC.

On the basis of 16S rRNA gene sequence similarity values (data available in IJSEM Online), strain $\mathrm{YK}-1^{\mathrm{T}}$ falls within the 'Epsilonproteobacteria' and is most closely related to Thiomicrospira species [Thiomicrospira denitrificans (90.1\%) and Thiomicrospira sp. strain CVO (90.0\%)]. A phylogenetic dendrogram based on 16S rRNA gene sequences (Fig. 2) shows the relationship of strain $\mathrm{YK}-1^{\mathrm{T}}$ to other strains in the 'Epsilonproteobacteria'. Previously, we have classified the 16S rRNA gene sequences of the Thiovulum subgroup into four assemblages, namely Thiovulum, marine symbiont, groundwater bacteria and Thiomicrospira denitrificans assemblages (Watanabe et al., 2000). Strain $\mathrm{YK}-1^{\mathrm{T}}$ is the sole isolate belonging to the groundwater-bacteria assemblage.

The reason for creating a new genus for strain $\mathrm{YK}-1^{\mathrm{T}}$ was the high sequence divergence from related genera. Moreover, we found several distinct features of strain $\mathrm{YK}-1^{\mathrm{T}}$ that could clearly separate it from strains of Thiomicrospira (Thiomicrospira denitrificans and Thiomicrospira sp. CVO); these features include habitat, motility, $\mathrm{NaCl}$ sensitivity, inability to utilize acetate as carbon source, ability to utilize hydrogen gas as electron donor, end product from sulfide oxidation and inability to utilize nitrite as electron acceptor. Another isolated member of the Thiovulum subgroup, Thiovulum sp., is also a sulfur-oxidizing bacterium; however, its features described in the literature (Riviere \& Schmidt, 1992) are quite different from those of strain $\mathrm{YK}-1^{\mathrm{T}}$. Thiovulum sp. grows only under microaerobic conditions by reducing molecular oxygen, and cells are round or ovoid (5-25 $\mu \mathrm{m}$ in diameter). From these results, strain $\mathrm{YK}-1^{\mathrm{T}}$ is considered to represent a new genus in the 'Epsilonproteobacteria'.

\section{Description of Sulfuricurvum gen. nov.}

Sulfuricurvum (Sul.fu.ri.cur'vum. L. neut. n. sulfur-uris sulfur; L. adj. curvus -a -um curved; N.L. neut. n. Sulfuricurvum curved bacterium that utilizes sulfur).

Chemolithoautotrophic and sulfur-oxidizing, capable of thriving under microaerobic and anaerobic conditions. Based on 16S rRNA gene sequence analysis, it represents a new lineage in the 'Epsilonproteobacteria'.

The sole and type species is Sulfuricurvum kujiense.

\section{Description of Sulfuricurvum kujiense sp. nov.}

Sulfuricurvum kujiense (ku.ji.en'se. N.L. neut. adj. kujiense referring to Kuji, Iwate Prefecture, Japan, where the bacterium was isolated).

Cells are curved rods (spiral cells are also observed in the exponential phase of growth) of $1-2 \times 0.4 \mu \mathrm{m}$ in size; motile by one polar flagellum. Gram-negative and non-sporeforming. Oxidase-positive and catalase-negative. Growth is observed only under low $\mathrm{NaCl}$ concentrations (below $1 \%$ ). Optimum growth temperature is $25^{\circ} \mathrm{C}$ (range $10-$ $35^{\circ} \mathrm{C}$ ); optimum $\mathrm{pH}$ is $7 \cdot 0$ (range $6 \cdot 0-8 \cdot 0$ ). Grows anaerobically and microaerobically by oxidizing reduced sulfur species, such as sulfide, elemental sulfur and thiosulfate, and hydrogen. Molecular oxygen and nitrate serve as sole electron acceptors. Grows autotrophically on carbon dioxide and bicarbonate; no growth occurs with organic acids, such as acetate, lactate, pyruvate, succinate and formate, or sugars. Does not utilize nitrite as an electron acceptor, and nitrite is the terminal product of nitrate reduction. DNA $\mathrm{G}+\mathrm{C}$ content is $45 \mathrm{~mol} \%$. Isolated from drain water from an underground crude-oil storage cavity in Kuji, Iwate, Japan. 
The type strain is $\mathrm{YK}-1^{\mathrm{T}}\left(=\mathrm{JCM} 11577^{\mathrm{T}}=\mathrm{MBIC} 06352^{\mathrm{T}}\right.$ $=$ ATCC BAA- $921^{\mathrm{T}}$ ).

\section{Acknowledgements}

We thank Koichi Nakagaki and Yoichi Matsumura for their kind help in the sampling of groundwater. We also thank Hiroshi Urata and Mika Atsumi for electron microscopy, Miyuki Nishijima for $\mathrm{G}+\mathrm{C}$ analysis and Sachiko Kawasaki and Midori Satoh for technical assistance.

\section{References}

Beveridge, T. J., Popkin, T. J. \& Cole, R. M. (1994). Electron microscopy. In Methods for General and Molecular Bacteriology, pp. 42-71. Edited by P. Gerhardt, R. G. E. Murray, W. A. Wood \& N. R. Krieg. Washington, DC: American Society for Microbiology.

Corre, E., Reysenbach, A.-L. \& Prieur, D. (2001). Epsilonproteobacterial diversity from a deep-sea hydrothermal vent on the Mid-Atlantic Ridge. FEMS Microbiol Lett 205, 329-335.

Engel, A. S., Lee, N., Porter, M. L., Stern, L. A., Bennett, P. C. \& Wagner, M. (2003). Filamentous "Epsilonproteobacteria" dominate microbial mats from sulfidic cave springs. Appl Environ Microbiol 69, 5503-5511.

Gevertz, D., Telang, A. J., Voordouw, G. \& Jenneman, G. E. (2000). Isolation and characterization of strains $\mathrm{CVO}$ and FWKO $\mathrm{B}$, two novel nitrate-reducing, sulfide-oxidizing bacteria isolated from oil field brine. Appl Environ Microbiol 66, 2491-2501.

Gutell, R. R. (1994). Collection of small subunit (16S- and 16S-like) ribosomal RNA structures: 1994. Nucleic Acids Res 22, 3502-3507.

Jukes, T. H. \& Cantor, C. R. (1969). Evolution of protein molecules. In Mammalian Protein Metabolism, vol. 3, pp. 21-132. Edited by H. N. Munro. New York: Academic Press.

Kodama, Y. \& Watanabe, K. (2003). Isolation and characterization of a sulfur-oxidizing chemolithotroph growing on crude oil under anaerobic conditions. Appl Environ Microbiol 69, 107-112.

Lomans, B. P., Maas, R., Luderer, R., den Camp, H. J. M. O., Pol, A., van der Drift, C. \& Vogels, G. D. (1999). Isolation and characterization of Methanomethylovorans hollandica gen. nov., sp. nov., isolated from freshwater sediment, a methylotrophic methanogen able to grow on dimethyl sulfide and methanethiol. Appl Environ Microbiol 65, 3641-3650.

Madrid, V. M., Taylor, G. T., Scranton, M. I. \& Chistoserdov, A. Y. (2001). Phylogenetic diversity of bacterial and archaeal communities in the anoxic zone of the Cariaco Basin. Appl Environ Microbiol 67, 1663-1674.

Maidak, B. L., Cole, J. R., Parker, C. T., Jr \& 11 other authors (1999). A new version of the RDP (Ribosomal Database Project). Nucleic Acids Res 27, 171-173.

Mesbah, M., Premachandran, U. \& Whitman, W. B. (1989). Precise measurement of the $\mathrm{G}+\mathrm{C}$ content of deoxyribonucleic acid by high-performance liquid chromatography. Int J Syst Bacteriol 39, 159-167.

Moyer, C. L., Dobbs, F. C. \& Karl, D. M. (1995). Phylogenetic diversity of the bacterial community from a microbial mat at an active, hydrothermal vent system, Loihi Seamount, Hawaii. Appl Environ Microbiol 61, 1555-1562.

Riviere, J. W. M. \& Schmidt, K. (1992). The genus Thiovulum. In The Prokaryotes, pp. 3492-3497. Edited by A. Balows, H. G. Trüper, M. Dworkin, W. Harder \& K. H. Schleifer. New York: Springer.

Smibert, R. M. \& Krieg, N. R. (1994). Phenotypic characterization. In Methods for General and Molecular Bacteriology, pp. 607-655. Edited by P. Gerhardt, R. G. E. Murray, W. A. Wood \& N. R. Krieg. Washington, DC: American Society for Microbiology.

Thompson, J. D., Higgins, D. G. \& Gibson, T. J. (1994). CLUSTAL W: improving the sensitivity of progressive multiple sequence alignment through sequence weighting, position-specific gap penalties and weight matrix choice. Nucleic Acids Res 22, 4673-4680.

Timmer-ten Hoor, A. (1975). A new type of thiosulfate oxidizing, nitrate reducing microorganism: Thiomicrospira denitrificans sp. nov. Neth J Sea Res 9, 344-350.

Watanabe, K., Watanabe, K., Kodama, Y., Syutsubo, K. \& Harayama, S. (2000). Molecular characterization of bacterial populations in petroleum-contaminated groundwater discharged from underground crude oil storage cavities. Appl Environ Microbiol 66, 4803-4809. 